\title{
Contribution of the Fundus Examination in the Management of General Pathologies in Hospital in Lomé-Togo
}

\author{
Nouhou Diori Adam ${ }^{*}$, Nonon Saa Kassoula Batomaguela1, Dzidzinyo Kossi ${ }^{1}$, \\ Abbey Abbevi Elie ${ }^{1}$, Abdou Zakou², Yacoubou Soumana ${ }^{3}$, Abdou Amza ${ }^{4}$, Komi Patrice Balo ${ }^{1}$ \\ ${ }^{1}$ Ophthalmology Department, Teaching Hospital Sylvanus Olympio, Lomé, Togo \\ ${ }^{2}$ Ophthalmology Department, Be District Hospital, Lomé, Togo \\ ${ }^{3}$ Clinique Lumière, Niamey, Niger \\ ${ }^{4}$ Ophthalmology Department, Lamordé National Hospital, Niamey, Niger \\ Email: *adamslalou@gmail.com
}

How to cite this paper: Adam, N.D., Batomaguela, N.S.K., Kossi, D., Elie, A.A., Zakou, A., Soumana, Y., Amza, A. and Balo, K.P. (2019) Contribution of the Fundus Examination in the Management of General Pathologies in Hospital in Lomé-Togo. Open Journal of Internal Medicine, 9, 52-61. https://doi.org/10.4236/ojim.2019.93008

Received: July 1, 2019

Accepted: August 18, 2019

Published: August 21, 2019

Copyright (c) 2019 by author(s) and Scientific Research Publishing Inc. This work is licensed under the Creative Commons Attribution International License (CC BY 4.0).

http://creativecommons.org/licenses/by/4.0/

\begin{abstract}
Many general conditions have an impact on the fundus. The purpose of our work was to study the epidemiological profile of patients referred to our service for a review of the fundus and analyze the results. It was a retrospective study description of the examinations of the fundus during the period from January 2016 to December 2017. In the ophthalmology department of the Lomé University Hospital Center, during the study period, 1019 consultations were recorded, of which 727 were for fundus $6.84 \%$. There were 336 men and 391 women, a sex ratio of 0.85 . The age group $40-69$ years accounted for $61.9 \%$. The frequency of the main reasons for the request was hypertension $54.2 \%(\mathrm{~N}=394)$; hypertension complicated or associated with other conditions (CKI, CKD, pregnancy and diabetes) accounted for $21.6 \%$ $(\mathrm{N}=157)$, headache associated with a decrease in visual acuity $8.25 \%(\mathrm{~N}=$ $60)$, diabetes $6.46 \%(\mathrm{~N}=47)$ and sickle cell disease $0.69 \%(\mathrm{~N}=5)$. Hospitalized patients $52.41 \%(\mathrm{~N}=381)$. The fundus was abnormal in 546 patients or $75.11 \%$. Hypertensive retinopathy was found $80.21 \%$ cases in hypertensive patients, diabetic retinopathy 43.42 in diabetic patients. Diabetics Fundus examination in hospital practice found a retinal lesion in three-quarters of cases. It so important to ask the examination of the fundus most often in the current pactise.
\end{abstract}

\section{Keywords}

Fundus, Hypertensive Retinopathy, Diabetic Retinopathy, Headache Lomé 


\section{Introduction}

Ophthalmological involvement is common in many general conditions with resounding on the fundus. The main pathologies are related to an attack inflammatory or vascular system including arterial hypertension, diabetes and other conditions systemic inflammatory. Their care goes through a diagnosis and the assessment of ocular repercussions because of the risk of blindness that they can represent [1]. Screening with a fundus of diabetic retinopathy found its prevalence in Africa is $47.8 \%$ in Maseru in Lesotho, $45.1 \%$ in Ilorin Nigeria, and 34\% in Lusaka Zambia [2]. This retinopathy is $39.2 \%$ associated with nephropathy according to Lokrou et al. [3]. Different teams (Beaver Dam Study, Atherosclerosis Risk in Communities (ARIC) and Blue Mountains study) studied the relationship between the fundus and the occurrence of pathology. Regardless of high blood pressure, there is an association between the presence of fundus abnormalities and the presence of white matter lesions at Magnetic resonance imaging (MRI) [relative risk (RR): 2.1 to 4] [4].

It has been shown that fundus involvement can be used as an indicator of target organ damage such as kidney, central nervous system and eye [5]. A study also showed that the risk for a patient to have a stroke at 3 years was $4 \%$ in the presence of white matter lesions on MRI (RR: 2.6) and 18\% (RR: 18.1) when specific retinal abnormalities were associated with hemorrhages deep rounds [4]. Clinical examination and specialized imaging techniques are often necessary in the detection of retinal lesions. However the most simple is the use of the direct ophthalmoscope. This is an atraumatic examination, although supported by the patient, achievable both in the ophthalmology department and at the bedside hospitalized patient. Performing a complete retinal examination requires a pupil completely dilated. Pupillary dilation can be obtained by various agents including Tropicamide 1\%, Phenylephrine 2.5\%, and Cyclopentolate $1 \%$. Generally, it is not necessary to use pharmacological agents of action prolonged [6].

The purpose of our work is to study the epidemiological profile of patients referred in our service for a review of the fundus and analyze the results

\section{Patients and Methods}

This was a retrospective and descriptive study conducted in the ophthalmology department of the University Hospital Sylvanus Olympio (CHU-SO) of Lomé from January 2016 to December 2017. We included in the study all patients referred by practitioners hospitals for an examination of the fundus externally or hospitalized in the different services of the said center outside the ophthalmic service. Patients who were excluded came for other results than the examination of the fundus. The realization of the fundus in the hospitalized patients was practiced at bedside on their hospital beds after dilating both eyes with Tropicamide $1 \%$. A drop was administered all 15 minutes for 30 minutes before the practice of the exam. Some who could move were examined in the service as all 
those who were addressed from the external consultation. Direct or indirect ophthalmoscopy was used for the realization of the exam. This is the portable direct ophthalmoscope for hospitalized patients and the Volk 90D lens for some who have moved into the service. The data are collected from patient records and the consultation register. The variables studied are: socio-demographic data, clinical history, patterns of fundus request, clinical results of fundus examination. Classifications used are Keith and Wagener for hypertensive retinopathy, ALFEDIAM for diabetic retinopathy. All of this collected data was captured and analyzed using the software EPI-Info version 7 and Microsoft Excel 2013. The difference between the variables was appreciated at using the Chi-square test, with a threshold of significance set at 0.05 . The limit of the study was essentially the fact that it did not take into account the others hospital centers.

\section{Results}

\subsection{Epidemiological Data}

Of the 1019 patients consulted during study period 727 were referred for review fundus is a frequency of $6.84 \%$. Inpatients accounted for 381 cases, or $52.41 \%$. Whose majority were hospitalized in cardiology 178 cases or $24.48 \%$. Patients referred from the consultation 346 cases or $47.59 \%$ (Table 1).

\subsection{Age and Sex}

The mean age was 48 years $(\mathrm{SD}=16.42)$ with extremes ranging from 1 year to 90 years. The age group 40 - 69 years was the most represented with 450 cases or $61.9 \%$. There were 336 men and 391 women is a sex ratio of 0.85 .

Table 1. Distribution of patients by recruitment method.

\begin{tabular}{lcc}
\hline \multicolumn{1}{c}{ RECRUITMENT MODE } & Numbers & $\%$ \\
\hline 1) Hospitalized patients & 381 & $52.41 \%$ \\
$>$ cardiology & 178 & $24.48 \%$ \\
$>$ surgery & 5 & $0.69 \%$ \\
$>$ gynecology & 42 & $5.78 \%$ \\
$>$ internalmedicine & 60 & $8.25 \%$ \\
$>$ nephrology & 5 & $0.69 \%$ \\
$>$ neurology & 40 & $5.50 \%$ \\
$>$ pavillon military & 5 & $0.69 \%$ \\
$>$ pediatrics & 19 & $2.61 \%$ \\
$>$ pneumology & 8 & $1.10 \%$ \\
$>$ rheumatology & 2 & $0.28 \%$ \\
$>$ emergency room & 17 & $2.34 \%$ \\
2) Patients from outpatient & 346 & $47.59 \%$ \\
Total & 727 & $100 \%$ \\
\hline
\end{tabular}




\subsection{Reasons for Requesting the Examination}

First reason: pure hypertension (HTA) 394 cases or 54.20\%, complicated hypertension or associated with other general conditions (stroke, insufficiency) chronic renal disease (CKD), pregnancy and diabetes) accounted for 157 cases, or $21.6 \%$ (Table 2). The headache associated with a decrease in visual acuity 60 cases, is $8.25 \%$ (Table 3 ); diabetes 47 cases $6.46 \%$.

\subsection{Results of the Fundus Examination}

Of the 727 patients included, the fundus was normal in 174 cases or $23.93 \%$, abnormal in 546 cases or $75.11 \%$ and inaccessible because of intraocular disorders bilateral in 7 cases, is $0.96 \%$.

In hypertensive patients, the fundus was abnormal in 450 cases or $81.67 \%$, and the hypertensive retinopathy accounted for 442 cases or $80.21 \%$. Stage III of

Table 2. Patient distribution according to the fundus request pattern.

\begin{tabular}{lcc}
\hline \multicolumn{1}{c}{ REASON FOR THE APPLICATION OF THE FO } & Numbers & $\%$ \\
\hline $\begin{array}{l}\text { 1) Hypertension (hypertension) pure, complicated, and } \\
\text { associated with other general conditions }\end{array}$ & 551 & $75.79 \%$ \\
$\checkmark$ Hypertension (hypertension) & 394 & $54.20 \%$ \\
$\checkmark$ HTA and pregnancy & 102 & $14.03 \%$ \\
$\checkmark$ HTA complicated stroke (stroke) & 21 & $2.89 \%$ \\
$\checkmark$ HTA + diabetes & 29 & $3.99 \%$ \\
$\checkmark$ Hypertension and chronic renal failure & 5 & $0.69 \%$ \\
2) Decreased visual acuity (BAV) and headache & 60 & $8.25 \%$ \\
3) Diabetic & 47 & $6.46 \%$ \\
4) Intracranial hypertension syndrome & 23 & $3.16 \%$ \\
5) Sickle cell & 5 & $0.69 \%$ \\
6) Megalocornea & 4 & $0.55 \%$ \\
7) Pre-therapeutic assessment & 9 & $1.24 \%$ \\
8) Strabisme & 9 & $1.24 \%$ \\
9) Syndrome meningeal & 7 & $0.96 \%$ \\
10) Toxoplasmosis brain & 9 & $1.24 \%$ \\
11) Burkitt's lymphoma & 3 & $0.41 \%$ \\
Total & 727 & $100 \%$ \\
\hline
\end{tabular}

Table 3. Distribution of patients by headache and BAV.

\begin{tabular}{ccc}
\hline RESULTS & Numbers & $\%$ \\
\hline normal & 11 & $18.33 \%$ \\
Retinal degenerative lesions (AMD, retinitis pigmentosa) & 10 & $16.67 \%$ \\
Suspicion of bilateral glaucomatous opticneuropathy & 35 & $58.33 \%$ \\
Hypertensive retinopathy & 4 & $6.67 \%$ \\
Total & 60 & $100.00 \%$ \\
\hline
\end{tabular}


Keith and Wagener was the most common with 146 cases or $26.50 \%$ (Figure 1).

In diabetic patients the fundus was abnormal in 55 cases, is $72.36 \%$. A diabetic retinopathy was present in 33 cases $43.42 \%$. Diabetic retinopathy not Proliferation was predominant with 23 cases, is $30.26 \%$ (Figure 2). Stage II hypertensive retinopathy was predominant in $38.10 \%$ of patients with patients with stroke according to the Keith and Wagner classification (Table 4).

Other affections see (Table 5).

\section{CLASSIFICATION DE KEITH ET WAGENER}

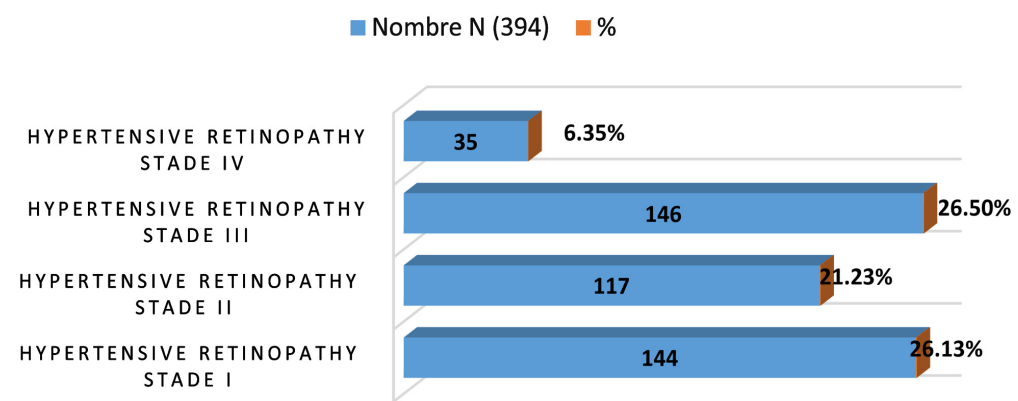

Figure 1. Distribution of hypertensive patients according to the Keith and Wagner classification.

\section{CLASSIFICATION AFEDIAM}

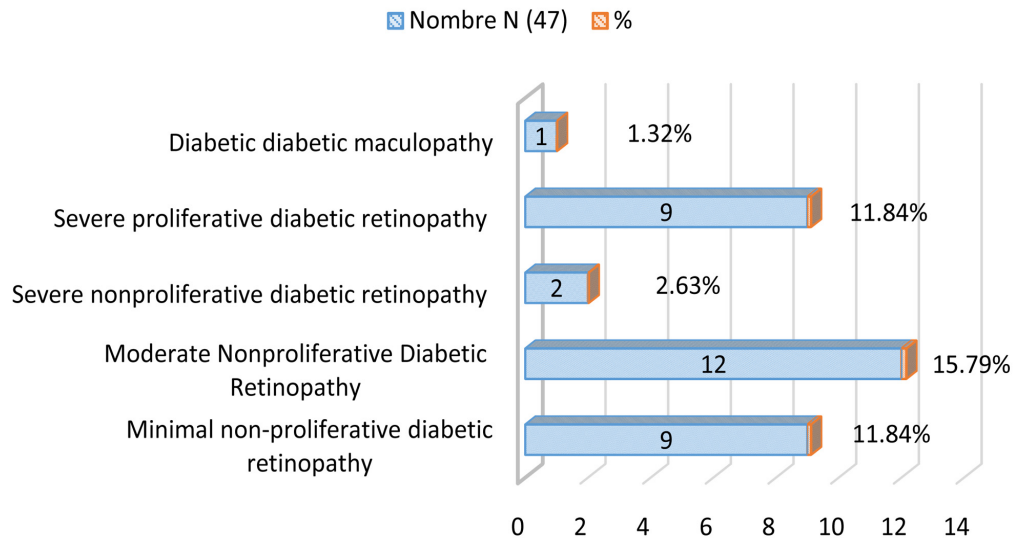

Figure 2. Distribution of diabetic patients according to the classification of ALFEDIAM.

Table 4. Repartition of stroke patients according to the classification of Keith and Wagner.

\begin{tabular}{ccc}
\hline Stadium & Number N (21) & $\%$ \\
\hline retinopathy Stage I hypertensive & 4 & $19.05 \%$ \\
retinopathy Stage II hypertensive & 8 & $38.10 \%$ \\
retinopathy Stage III hypertensive & 4 & $19.05 \%$ \\
retinopathy Stage IV hypertensive & 3 & $14.29 \%$ \\
\hline
\end{tabular}


Table 5. Distribution of other lesions of the posterior pole.

\begin{tabular}{ccc}
\hline Other lesions of the posterior pole & Number $\mathbf{N}=\mathbf{7 2 7}$ & $\%$ \\
\hline Suspicion of Bilateral Glaucomatous Optic Neuropathy & 35 & $4.81 \%$ \\
Papillaryedema & 7 & $0.96 \%$ \\
Retinitis pigmentosa & 7 & $0.96 \%$ \\
Sickle cell & 4 & $0.55 \%$ \\
Age-related macular degeneration (AMD) & 5 & $0.69 \%$ \\
Congenital glaucoma & 3 & $0.41 \%$ \\
\hline
\end{tabular}

\section{Discussion}

\subsection{Epidemiological Aspects}

In our study the fundus examination accounted for $6.84 \%$, which is lower than the Diallo et al. In Burkina in 2015 which was 7.37\% [7]. This could be explained by the fact that our study was conducted in a hospital setting. The average age of our patients was 48 years with an age range of $40-69$ years which is superior to the results of the same author who found an average age of 42 years with an age range of 40 - 59 years. Women was the most represented in our study $53.78 \%$ however the same study noted a male predominance. This could be explained by the recruitment of patients from the gynecology.

The main indications of the request for a fundus examination were the balance sheets of resonance of high blood pressure, headaches associated with lowering of acuity visual, diabetes.

\subsection{Clinical Aspects}

\section{Hypertension}

High blood pressure (hypertension) is one of the major risk factors for mortality and cardiovascular morbidity in the world [8] [9] [10]. It is a cardiovascular risk factor major cause of stroke, kidney failure and stroke [5]. Mortality during pregnancy is the leading cause of death in the world [11] [12]. In Togo, a prevalence of $36.7 \%$ is reported in Lomé [13]. In our HTA study accounted for $54.20 \%$ of fundus requests, this frequency was significantly higher to that found by Diallo et al. in 2015 which $43.15 \%$ [7]. Hypertensive retinopathy was found in $80.21 \%$ of our study of which $20.63 \%$ of hypertensive retinopathies were stage III; this same observation was made in the thesis of Yaméogo et al. in a hospital Bobo Dioulasso who found a higher frequency of $65.3 \%$ of cases of retinopathy stage III hypertensive in the same classification [14]. We can see that hospitalized patients had more advanced retinopathies may be related to the decompensation of the disease. Achievement of the fundus can be used as an indicator of organ involvement target such as kidney, central nervous system and eye [5]. Wong et al reported that hypertensive retinopathy is an indicator of risk of morbidity and mortality systemic [15]. Hypertensive patients complicated with stroke accounted for $2.89 \%$ in our study. Stage II accounted for $38.10 \%$, Ame- 
dome et al. 2016 also found a lower frequency in $32.4 \%$ at the same stage [16].

In our study the preeclampsia-eclampsia prevalence was $14.03 \%$; $75.49 \%$ of pre-eclamptic and $24.51 \%$ of eclamptics. Ngwanou et al. in Cameroon in 2015 hadfound a pre-eclamptic and eclamptic prevalence of $7.08 \%$ with $62.8 \%$ pre-eclamptic and $37.2 \%$ eclamptic [17]. The fundus summer pathological in women pregnant in $79.41 \%$ in our study against the same author found a frequency less than $48.8 \%$.

Hypertension associated with diabetes was found in $4 \%$ of cases in our study. F. Damorou et al. in 2008 in Togo found 7\% the association between the two [18]. On the other hand Diallo et al. found a higher frequency of $10.27 \%$. The fundus examination allows the diagnosis and monitoring of hypertensive patients and even to predict certain cerebrovascular complications, hence the interest of a demand systematically by cardiologists.

\section{Headaches and decreased visual acuity}

Headache is one of the most common reasons for consultation in ophthalmology [19] [20]. The headaches associated with the AVB come in second position after HTA as a fundus request pattern representing $8.25 \%$ in our study. D. Kaimbo WA Kaimbo et al. in 2003 found a higher frequency of 15.6\% [21]; at Ramatoulaye Kane et al. in 2017, the decrease in visual acuity was the main reason for consultation Ophthalmology (55.9\%) followed by headache (23.1\%) [22]. This lower frequency could be explained by the fact that we only included those who come for examination from the fundus. The posterior pole lesions observed at the fundus were mainly suspicion of glaucomatous optic neuropathy in $58.33 \%$, followed by retinopathy hypertensive in $6.67 \%$ and other lesions (age-related macular degeneration, retinitis pigmentary) in $16.67 \%$. The same author had found a papillary pallor in $21 \%$, followed vascular alterations related to hypertension in $16 \%$ and other lesions (degeneration macular, retinitis pigmentosa) in $13 \%$.

\section{Diabetes}

Diabetic retinopathy (DR) is a manifestation of microangiopathy occurring beyond 10 to 20 years of evolution of the diabetic disease. It is an important cause of low vision and the leading cause of blindness in people under 60 in countries industrialized countries [23] [24]. In Africa, several studies have been conducted to evaluate the frequency and to analyze the characteristics of diabetic retinopathy [25] [26]. In Togo Balo et al. in 1995 reported a prevalence of 52\% [27]. In Burkina Faso studies in hospitals in Ouagadougou Sawadogo reports a frequency lower than our RD of $37.5 \%$ and Medica $43.1 \%$ [28] [29]. The latter was similar to $43.42 \%$. This could be explained that hospitalized patients would have unbalanced diabetes and poorly monitored diabetes. Diallo et al. Burkina Faso found a lower rate of $25.92 \%$ [7]. Non-proliferative retinopathy was $30.26 \%$ in our study; however, the same author had found $24.53 \%$ of non-proliferative diabetic retinopathy. The diagnosis of diabetic retinopathy is based on a biomicroscopy examination of the fundus after pupillary dilatation. This examination 
makes it possible to identify the different signs of the Diabetic retinopathy. Complications of $\mathrm{RD}$ are causes of blindness and low vision. They can be avoided by early management of $\mathrm{RD}$, annual fundus monitoring in diabetic patients [30] [31].

\section{Conclusion}

The hospital demand for a fundus examination represents a considerable activity on the total of ophthalmic consultations which is $6.84 \%$. Its realization helps to assert some diagnoses to other cerebrovascular complications. Retinal lesions are more severe in hospitalized patients. In our work setting, hypertension blood pressure, headaches associated with decreased visual acuity, and diabetes were the main reasons for application. All hospital practitioners must request an examination of the fundus of the at-risk population in order to improve the quality of the patient load.

\section{Conflicts of Interest}

The authors declare no conflict of interest.

\section{Contributions of the authors}

All authors state that they have read and approved the final version of the manuscript.

\section{References}

[1] Saadoun (2017) Eil et maladies inflammatoires. Réalités Ophtalmologiques, 240, 57.

[2] Sidibe, E.H. (2000) Rétinopathie diabétique à Dakar et revue de la littérature Africaine. Diabetes \& Metabolism, 26, 322-324.

[3] Lokrou, A. and Debekambou, H.M.F. (1994) La néphropathie patente du diabétique africain en cote divoire. Etude transversale d'une population de 446 patients. Rev Fr Endocr Clin Metab, 35, 545-550.

[4] Gaudric, A. (2017) Rétinopathie hypertensive. JIFRO-CEil et médecine interne, réalités Ophtalmologiques. Mars, 240, 62-64.

[5] Hobanian, A.V., Bakris, G.L., Black, H.R., et al. (2003) The Seventh Report of the Joint National Committee on Prevention, Detection, Evaluation, and Treatment of High Blood Pressure: The JNC 7 Report. JAMA, 289, 2560-2572. https://doi.org/10.1001/jama.289.19.2560

[6] Friberg, T.R. (2008) Examination of the Retina: Ophthalmoscopy and Fundus Biomicroscopy. In: Albert, D.M., Miller, J.W., Azar, D.T. and Blodi, B.A., Eds., Albert \& Jakobiec's Principles and Practice of Ophthalmology, 3rd Edition, Saunders, Philadelphia, Chap. 127.

https://doi.org/10.1016/B978-1-4160-0016-7.50130-2

[7] Diallo, J.W., et al. (2015) Intérêts de l'examen du fond d'œil en pratique de ville: Bilan de 438 cas. The Pan African Medical Journal, 20, 363. https://doi.org/10.11604/pamj.2015.20.363.6629

[8] Barylski, M., Małyszko, J., Rysz, J., Mysliwiec, M. and Banach, M. (2011) Lipids, 
Blood Pressure, Kidney: What Was New in 2011. Archives of Medical Science, 7, 1055-1066. https://doi.org/10.5114/aoms.2011.26620

[9] Kearney, P.M., Whelton, M., Reynolds, K., Muntner, P., Whelton, P.K. and He, J. (2005) Global Burden of Hypertension Analysis of World Wide Data. The Lancet, 365, 217-223. https://doi.org/10.1016/S0140-6736(05)17741-1

[10] Bah, A.O., Diallo, M.H., Conde, A.M. and Keita, N. (2001) Hypertension artérielle et grossesse: Mortalité maternelle et périnatale. Médecine d'Afrique Noire, 48, 461.

[11] Bielecka, D.A., Aronow, W.S., Rysz, J. and Banach, M. (2011) The Rise and Fall of Hypertension: Lessons Learned from Eastern Europe. Current Cardiovascular Risk Reports, 5, 174-179. https://doi.org/10.1007/s12170-010-0152-2

[12] Banach, M., Mikhailidis, D.P., Kjeldsen, S.E. and Rysz, J. (2009) Time for New Indications for Statins. Medical Science Monitor, 15, 1-5.

[13] Yayehd, K., Damorou, F., Akakpo, R., Tchérou, T., N’D, N.W., Pessinaba, S., et al. (2013) Prévalence d'hypertension artérielle et description de ses facteurs de risque à Lomé (Togo): Résultats d'un dépistage réalisé dans la population générale en mai 2011. Annales de Cardiologie et d'Angéiologie, 62, 43-50.

https://doi.org/10.1016/j.ancard.2012.09.006

[14] Yaméogo, A.A. (1997) Etude du profil épidémiologique, clinique et évolutif de l'hypertension artérielle en milieu hospitalier de Bobo Dioulasso. Thèse de médecine, Ouagadougou Burkina Faso: Université de Ouagadougou Faculté des Sciences de la Santé (FSS) section médecine, No. 16, 135.

[15] Wong, T.Y. and McIntosh, R. (2005) Hypertensive Retinopathy Signs as Risk Indicators of Cardiovascular Morbidity and Mortality. British Medical Bulletin, 73-74, 57-70. https://doi.org/10.1093/bmb/ldh050

[16] Amedome, K.M., Guinhouya, K.M., Ayena, K.D., Vonor, K., Dzidzinyo, K., Maneh, N., et al. (2016) Rétinopathie au cours des AVC au centre hospitalier et universitaire Sylvanus-Olympio de Lomé au Togo. Journal de la Recherche Scientifique de I Université de Lomé (Togo), 18, 107-113. https://doi.org/10.1016/j.jfo.2016.07.012

[17] Ngwanou, N.A., Koki, G., Épée, E., Esiene, A., Mbu, R. and Bella, A.L. (2015) Les Lésions Rétiniennes au Cours de la Prééclampsie/éclampsie et leur Valeur Prédictive sur le Devenir de la Grossesse. Health Sciences and Diseases, 16, 1-6.

[18] Damorou, F., Togbossi, E., Pessinaba, S. and Soussou, B. (2008) Epidémiologie et circonstances de découverte de l'hypertension artérielle(HTA) en milieu hospitalier à Kpalime (ville secondaire du Togo). Mali Médical, 13, 17-20.

[19] Duke-Elder (1970) Ophthalmic Optics and Refraction. Vol. V. System of Ophthalmology. Henry Kimpton, London.

[20] Massiou, H. and Bousse, M.G. (1993) Céphalées: Aspects Cliniques. Editions Techniques. Encyclopédie Médico-Chirurgicale (Paris-France). Neurologie 17-023A-50.

[21] Kaimbo, D. and Kaimbo, W.A. (2003) Missotten. Céphalées en ophtalmologie. Journal Français D' Ophtalmologie, 26, 134-137.

[22] Kane, R., et al. (2017) Etude du glaucome primitif a angle ouvert à l'institut d'ophtalmologie tropicale africaine, Mali. Mali Médical, 3251, 9-12.

[23] Sinclair, S.H. (2006) Diabetic Retinopathy: The Unmet Needs for Screening and Review of Potential Solutions. Expert Review of Medical Devices, 3, 301-316. https://doi.org/10.1586/17434440.3.3.301

[24] Franck, R.N. (2004) Diabetic Retinopathy. The New England Journal of Medicine, 350, 48-58. https://doi.org/10.1056/NEJMra021678 
[25] Koki, G., Bella, A.L., Ongboua, E.A., Epée, E., Sobngui, E., kouanane, K.A., Ebana, M., et al. (2009) Rétinopathie du diabétique du noir africain étude agiographique. Revue SOAO, 2, 12-18.

[26] Demedeiros, Q.M., Ndiaye, P.A., Cissé, A., Wane, A., Diop, S.N., Ndoye-Roth, P.A., et al. (2003) Les aspects épidémiologiques et angiofluorographiques de la rétinopathie diabétique au Sénégal. Journal Français D’Ophtalmologie, 26, 160-163.

[27] Balo, K.P., Mensah, A. and Koffi Gue, B. (1995) La rétinopathie diabétique: Une étude angiofluographique chez le Noir Africain. Medecine d Afrique Noire, 42, 402-405.

[28] Sawadogo, N. (1997) Etude des aspects épidémiologiques et cliniques des principales complications oculaires au cours du diabète sucre au centre hospitalier national Yalgado Ouédraogo. Ouagadougou Burkina Faso: Thèse de médecine, Université de Ouagadougou Faculté des Sciences de la Santé (FSS) section médecine. 175.

[29] Méda, N., Tiono, H., Ahnoux-Zabsonre, A., Djiguimdé, W., Nabaloum, Y. and Drabo, J. (2010) La rétinopathie diabétique au Burkina Faso: Etat des lieux. Rev Société Ouest Afr d'Ophtalmologie, 1, 20-26.

[30] Massin, P., Angioi-Duprez, K., Bacin, F., Cathelineau, G., Chaine, G., Coscas, G., et al. (1997) Recommandations de l'alfediam pour le dépistage, la surveillance et le traitement de la Rétinopathie diabétique. Journal Français D’Ophtalmologie, 20, 302-310.

[31] Agence nationale d'accréditation (ANAES) (1999) Suivi du patient diabétique de type 2 à L'exclusion du suivi des complications oculaires. Diabetes \& Metabolism, $25,35-38$. 